\title{
PREPARATION AND CHARACTERIZATION OF HIGH-DISPERSED Pt/C NANO-ELECTROCATALYSTS FOR FUEL CELL APPLICATIONS
}

\author{
Hoang Anh Huy', Tran Van Man ${ }^{2}$, Huynh Thien Tai $^{3}$, Van Thi Thanh $\mathrm{Ho}^{3}$, \\ ${ }^{1}$ HoChiMinh City University of Technology, 268 Ly Thuong Kiet Street, \\ District 10, Ho Chi Minh City \\ ${ }^{2}$ HoChiMinh City University of Science, 227 Nguyen Van Cu, District 5, Ho Chi Minh City \\ ${ }^{3}$ HoChiMinh City University of Natural Resources and Environment, 236B Le Van Sy, \\ Tan Binh District, Ho Chi Minh City \\ *Email: httvan@hcmunre.edu.vn
}

Received: 1 November 2015; Accepted for publication: 2 June 2016

\begin{abstract}
Synthesis conditions are keys to control size and dispersion of Platinum $(\mathrm{Pt})$ nanoparticle (NP) structures that are the most important factors in improving the electrochemical activity and durability of electrodes in low temperature fuel cells. In this study, five catalyst samples $\mathrm{Pt}$ nanoparticles on carbon support ( $\mathrm{Pt} \mathrm{NPs} / \mathrm{C}$ ) have been synthesized by the simple and facile method at $30^{\circ} \mathrm{C}$ or $60{ }^{\circ} \mathrm{C}$ in $\mathrm{pH}=6.5$ or $\mathrm{pH}=11$ solution with or without using ethylene glycol (EG). The morphology, size, dispersion and activity of Pt NPs/C were characterized by using Xray diffraction (XRD), Transmission electron microscopy (TEM) and Cyclic Voltammetry (CV) in order to evaluate the effectiveness of this synthesis process. We found that the size, morphology and dispersion of $\mathrm{Pt} \mathrm{NPs} / \mathrm{C}$ were strongly affected by adjusting the temperature, $\mathrm{pH}$ and the presence of ethylene glycol. Finally, through determining electrochemically active surface area of a typical catalytic sample, we were able to conclude that the procedure have been established to reach goals simple, inexpensive but still can improve the catalytic activity for methanol oxidation reaction in direct methanol fuel cell (DMFC).
\end{abstract}

Keywords: Pt/C, Pt nanoparticles, Pt electrochemical active surface area, Pt/C catalyst, PtNPs/C.

\section{INTRODUCTION}

Platinum is one of the most active metal catalysts at room temperature for electrochemical reactions of fuel cells. Its activity is strongly dependent on the shape, size and particles' size distribution which can be controlled through synthesis conditions as the temperature, $\mathrm{pH}$ and enhancer. In practical cases, highly dispersed Pt catalysts with large surface areas are extremely important to increase the electrocatalytic activity $[1,2]$. To achieve a catalytic surface area large and high activity, it requires understanding the relationship between the catalytic activity and their structure/composition, which are the basis for rational design of highly efficient 
electrocatalysts for fuel cells and other electrochemical processes. The conventional preparation techniques based on wet impregnation and the chemical reduction of metal precursors do not provide satisfactory control of particle shape and size as well as the distribution of Pt particles on carbon support [3]. Synthesis of highly dispersed supporting platinum with uniform nanoparticle size still remains a challenge, especially for high metal loading. The conventional methods for the synthesis of Ptelectrocatalyst are mainly impregnation and colloid methods such as sulfite complex route and the colloidal route, the impregnation method usually produces NPs with large average particle sizes and broad size distributions while the colloidal route produces well-homogenized ultrafine Ptelectrocatalysts, however, the complexity of the latter hinders its utilization [4]. Many investigators have contributed many efforts to search alternative routes.

So far, there have been attempting to develop alternative synthesis methods based on microemulsions [5], sonochemistry [6] and microwave irradiation [7, 8], all of which are in principle more conducive to produce colloids and clusters on the nanoscale, and with greater uniformity.

In this study, a simple procedure for preparing Pt metal nanoparticles supported on carbon is reported. The uniform platinum nanoparticles supported on carbon with Pt loading up to 40 wt\% that is a standard amount in order to obtain higher dispersion and smaller crystallites [9]. This study set the stage for further inspections with the desire to create the best possible $\mathrm{Pt} / \mathrm{C}$ catalyst. Through this work, we found that the optimize preparation is simple, fast but it is able to control the particle size and distribution of Pt particles on the carbon support and could enhance the activity of catalyst for fuel cell applications.

\section{EXPERIMENTAL SECTION}

\subsection{Material used}

Vulcan XC-72R carbon with particle size $\sim 60 \mathrm{~nm}$ using as a support was purchased from Fuel Cell Store (USA). All the chemicals were of analytical grade; D521 Nafion Dispersion Alcohol based $1100 \mathrm{EW}$ at $5 \mathrm{wt} \%$, Ethyl alcohol pure ( $\geq 99.5 \%$, Acros), Hydrogen hexachloroplatinate (IV) hexahydrate, $99.9 \%$, (trace metal basis), 38 to $40 \% \mathrm{Pt}\left(\mathrm{H}_{2} \mathrm{PtCl}_{6} \cdot 6 \mathrm{H}_{2} \mathrm{O}\right.$ ), ethylene glycol (EG), acetone branded Acros (Belgium), sodium borohydride $\left(\mathrm{NaBH}_{4}\right)$, nitric acid $\left(\mathrm{HNO}_{3}\right)(65 \%$ - $68 \%)$ (China), Sulfuric acid (95.0 - 98.0\%) were used.

\subsection{Preparation of pre-treated Vulcan $\mathrm{XC}-72 \mathrm{R}$}

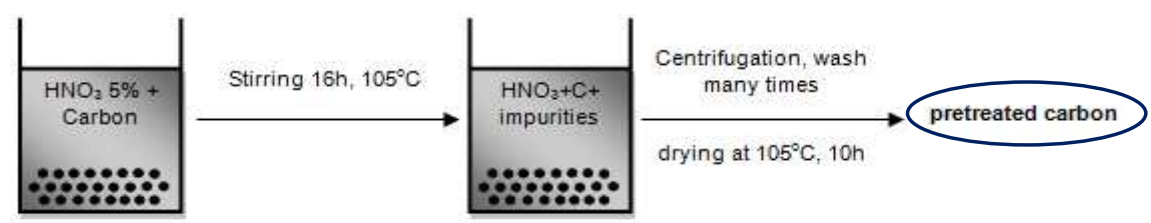

Figure 1. Preparation procedure of pre-treated Vulcan XC-72R.

Vulcan XC-72R carbon powder was treated to clean the contaminant in the commercial carbon. For example, $0.5 \mathrm{~g}$ carbon was dispersed in a round bottom flask with $500 \mathrm{~mL}$ of the $5 \% \mathrm{HNO}_{3}$ solution, the mixture was refluxed for 16 hours at $105^{\circ} \mathrm{C}$. Treated carbons were centrifuged with $4500 \mathrm{rpm}$ for several times with each 5 minutes for washing with de-ionized 
(DI) water and acetone $\left(15 \mathrm{~mL} \mathrm{H} \mathrm{H}_{2} \mathrm{O}\right.$ or Acetone for each centrifuge tubes), then dried at $105^{\circ} \mathrm{C}$ in an oven for 10 hours (Fig. 1) [10].

\subsection{Preparation of $\mathrm{Pt} / \mathrm{C}$ catalysts}

$\mathrm{Pt} / \mathrm{C}$ catalysts particles were synthesized by the following route: Pt particles were dispersed on the carbon supports by the following process: $50 \mathrm{mg}$ treated carbon was dispersed into the solvent (DI water with and without using EG), $3.39 \mathrm{~mL} \mathrm{H}_{2} \mathrm{PtCl}_{6} .6 \mathrm{H}_{2} \mathrm{O}$ with concentration 0.05 $\mathrm{M}$ into the mixed precursor. The $\mathrm{pH}$ of this mixture was adjusted to 6.5 and 11 by drop wise addition of $\mathrm{NaOH} 0.1 \mathrm{~N}$ solution. The mixture was stirred for $5 \mathrm{~min}$ and ultrasonicated for 15 minutes at room temperature. Then an excess amount of reduction agent $6.84 \mathrm{~mL} \mathrm{NaBH}_{4} 0.05 \mathrm{M}$ was added and the mixture was stirred by using a magnetic bar under atmospheric pressure at room temperature or $60^{\circ} \mathrm{C}$ for 2 hours (Fig. 2).

Finally, the synthesized catalyst particles $\mathrm{Pt} / \mathrm{C}$ were washed by DI water, centrifuged and dried for 12 hours at $100{ }^{\circ} \mathrm{C}$ [11]. All samples are shown in the Table 1 .

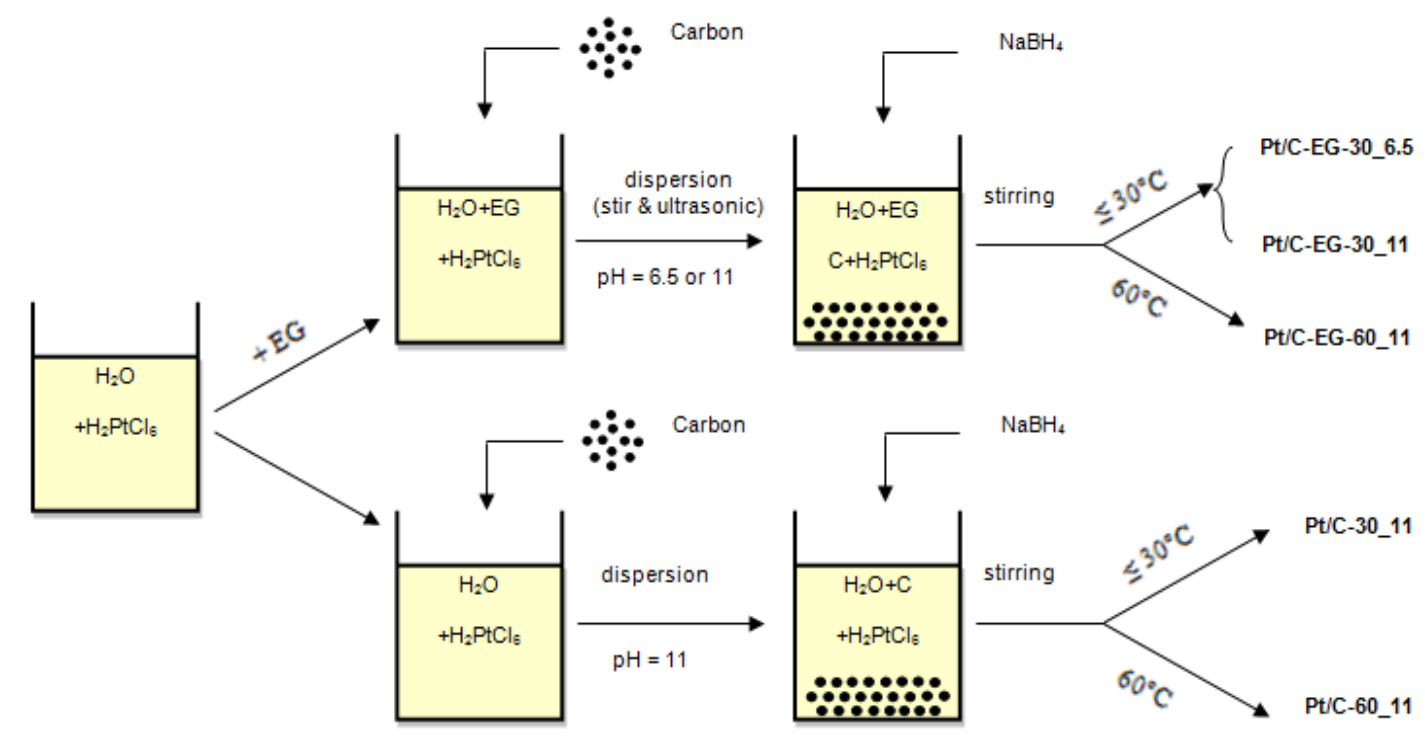

Figure 2. The preparation of $40 \mathrm{wt} \% \mathrm{Pt} / \mathrm{C}$ with different conditions ( $\mathrm{pH}$, temperature, using with and without $\mathrm{EG})$.

\subsection{XRD, TEM and CV Analysis}

The samples were characterized by using X-ray diffraction (XRD), Transmission electron microscopy (TEM), Cyclic voltammetry (CV) in order to assess catalytic activity of Pt particles through the effects of ethylene glycol, $\mathrm{pH}$ and temperature on the morphology, size and dispersion of platinum nanoparticles catalyst on carbon support for fuel cells.

$\mathrm{X}$-ray powder diffraction (XRD) patterns were recorded by using a $\mathrm{Cu} \mathrm{K} \alpha$ radiation source on a D8 Advance Bruker powder diffractometer (University of Technology-VNU HCM City). Transmission electron microscope (TEM) was taken by JEM-1400 (JEOL, Japan), (University of Technology-VNU HCM City). Cyclic Voltammetry (CV) was recorded by AutoLab machine system at Applied Physical Chemistry Laboratory, University of Science, VNU-HCM, Vietnam. 


\section{RESULTS AND DISCUSSION}

The samples of $40 \mathrm{wt} \% \mathrm{Pt} / \mathrm{C}$ catalysts were prepared with various conditions (Table 1 ). The effect of parameters such as EG, temperature as well as $\mathrm{pH}$ on the size, distribution of Pt NPs on carbon were studied. The samples were synthesized with and without using EG, carried out at room temperature $\left(30^{\circ} \mathrm{C}\right)$ and $60{ }^{\circ} \mathrm{C}$. The influence of $\mathrm{pH}$ value was also studied at 6.5 and 11.

Table 1. The samples of $40 \mathrm{wt} \% \mathrm{Pt} / \mathrm{C}$ catalysts were prepared with various conditions.

\begin{tabular}{cccl}
\hline $\begin{array}{c}\text { Ethylene } \\
\text { glycol (EG) }\end{array}$ & $\begin{array}{c}\text { Temperature } \\
\left({ }^{\circ} \mathbf{C}\right)\end{array}$ & $\mathbf{p H}$ & \multicolumn{1}{c}{ Catalysts } \\
\hline- & 30 & 11 & Pt/C-30_11 \\
EG & 30 & 11 & Pt/C-EG-30_11 \\
EG & 30 & 6.5 & Pt/C-EG-30_6.5 \\
EG & 60 & 11 & Pt/C-EG-60_11 \\
- & 60 & 11 & Pt/C-60_11 \\
\hline
\end{tabular}

\subsection{X-ray powder diffraction (XRD)}

The $40 \mathrm{wt} \% \mathrm{Pt} / \mathrm{C}$ samples are synthesized with the presence of EG and without EG at the room temperature and $60 \square \mathrm{C}$ in $\mathrm{pH}=6.5$ and 11 solutions. X-ray diffraction of these samples were shown in the Fig. 3. They indicated that all the broad diffraction peaks of the XRD patterns at $2 \theta=39.6,47.4,67.1^{\circ}$, corresponding to the reflections (111), (200), (220), respectively, which are consistent with the face centered cubic (fcc) structure of platinum (Pt), can be assigned to (JCPDS Card 04-0802), thus demonstrating the presence of crystalline Pt [12]. In addition, a broad peak at $2 \theta \approx 25^{\circ}$ was observed but not clearly due to the (002) plane of the hexagonal structure of the carbon support (Vulcan XC-72R) is amorphous carbon with small regions of graphitic properties [13].

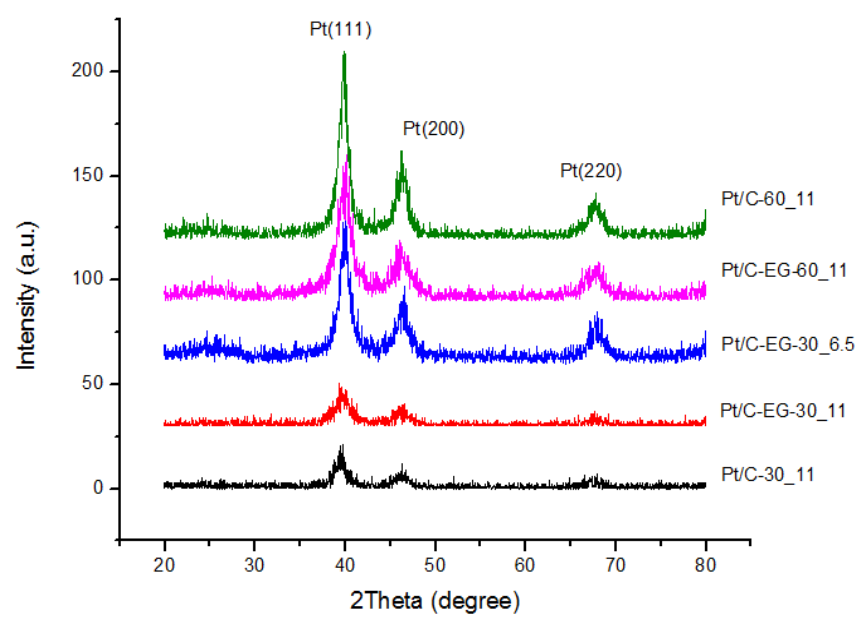

Figure 3. X-ray diffraction (XRD) patterns of $40 \mathrm{wt} \% \mathrm{Pt} / \mathrm{C}$ catalysts.

Table 2, the Pt/C sample with the presence of EG showed wider peak than the remaining samples in the preparation process, suggesting the Pt particles size of sample using EG, $\mathrm{pH}=11$ at room temperature $\left(30^{\circ} \mathrm{C}\right)$ is smallest $(3.84 \mathrm{~nm}$ ), (estimated from the Scherrer formula at $\mathrm{Pt}$ 
(111) peak).The largest active surface area of Pt is observed for sample Pt/C-EG-30_11 compared to other samples due to the small particle size of Pt as well as the higly dispersed Pt on the carbon support $\left(73 \mathrm{~m}^{2} / \mathrm{g}_{\mathrm{Pt}}\right)[14]$.

Scherrer equation:

$$
B(2 \theta)=\frac{K \lambda}{L \cos \theta} \longrightarrow L=\frac{0.9 \lambda}{B \cos \theta}
$$

where, $\mathrm{L}=$ average crystal size (angstrom or $\mathrm{nm}$ ); $\mathrm{B}=$ the full width half maximum of the peak; $\mathrm{K}=$ the Scherrer constant; depends on the how the width is determined, the shape of the crystal, and the size distribution; $\lambda=$ the wavelength of the radiation used to collect the data.

We used the Pt (111) plane to determine the average crystallite size. The FWHM is calculated from the (111) peak by using Originlab software. The value of $\mathrm{K}$ is 0.9 due to structure's Ptis face-centered cubic and the wavelength used to be $\lambda_{\mathrm{Cu}}=1.54 \mathrm{~A} \square$.

Surface areas of crystalline Pt were also calculated from the crystalline size using the following equation:

$$
S=\frac{6000}{\rho d}
$$

where, $d$ is the average crystallite size $(\mathrm{nm}), S$ is the average surface area $\left(\mathrm{m}^{2} \mathrm{~g}^{-1}\right)$ and $\rho$ is the density of $\mathrm{Pt}\left(21.4 \mathrm{~g} \mathrm{~cm}^{-3}\right)$. The sizes and surface areas are summarized in Table 2 .

Table 2. The average crystalline size and surface area were estimated from $(*)$ and $(* *)$.

\begin{tabular}{ccc}
\hline Catalysts & $\mathbf{L}_{\mathbf{X R D}}(\mathbf{n m})$ & $\mathbf{S}_{\mathbf{X R D}}\left(\mathbf{m}^{\mathbf{2}} / \mathbf{g}_{\mathbf{P t}}\right)$ \\
\hline Pt/C-30_11 & 7.14 & 39.3 \\
Pt/C-EG-30_11 & 3.84 & 73 \\
Pt/C-EG-30_6.5 & 7.72 & 36.3 \\
Pt/C-EG-60_11 & 5.85 & 48 \\
Pt/C-60_11 & 9.16 & 30.6 \\
\hline
\end{tabular}

\subsection{Transmission electron microscope (TEM)}

TEM picture and histogram of particle size distribution (Fig. 4) were consistent with calculating the crystallite size of Pt nanoparticles catalyst from the samples's XRD result. The TEM size $\mathrm{d}_{\text {TEM }}$ was determined using the following equation:

$$
d_{\text {TEM }}=\frac{\sum_{i=1}^{n} n_{i} d_{i}}{n}
$$

where, $n$ is the total number of measured particles, $n_{i}$ is the number of particles with a size $d_{i}$.

The size and surface area $\left(\mathrm{S}_{\mathrm{TEM}}\right)$ were estimated from TEM are shown in Table 3.

The Pt/C-EG-30_11 catalyst prepared using $\mathrm{NaBH}_{4}$ as the reducing agent in EG solution at $\mathrm{pH}=11$ has demonstrated that its particles size is smallest, the largest size belongs to $\mathrm{Pt} / \mathrm{C}$ 60_11 catalyst and particles size decreased in the following sequence: Pt/C-60_11 > Pt/C-EG30_6.5 > Pt/C-30_11 >Pt/C-EG-60_11 > Pt/C-EG-30_11, (Table 3). The presence of ethylene glycol (EG) supported Pt nanoparticles not only have narrow size, but they also distribute uniformly on carbon support (Fig. 4. (c), (e), (g)). This has been reported that the reaction with 
the attendance of EG and $\mathrm{NaBH}_{4}$ in a solution will form a complex reducing solution, and EG has performed roles as both a reducing agent for Pt reduction and a stabilizing for the reduced $\mathrm{Pt}$ nanoparticles [15].
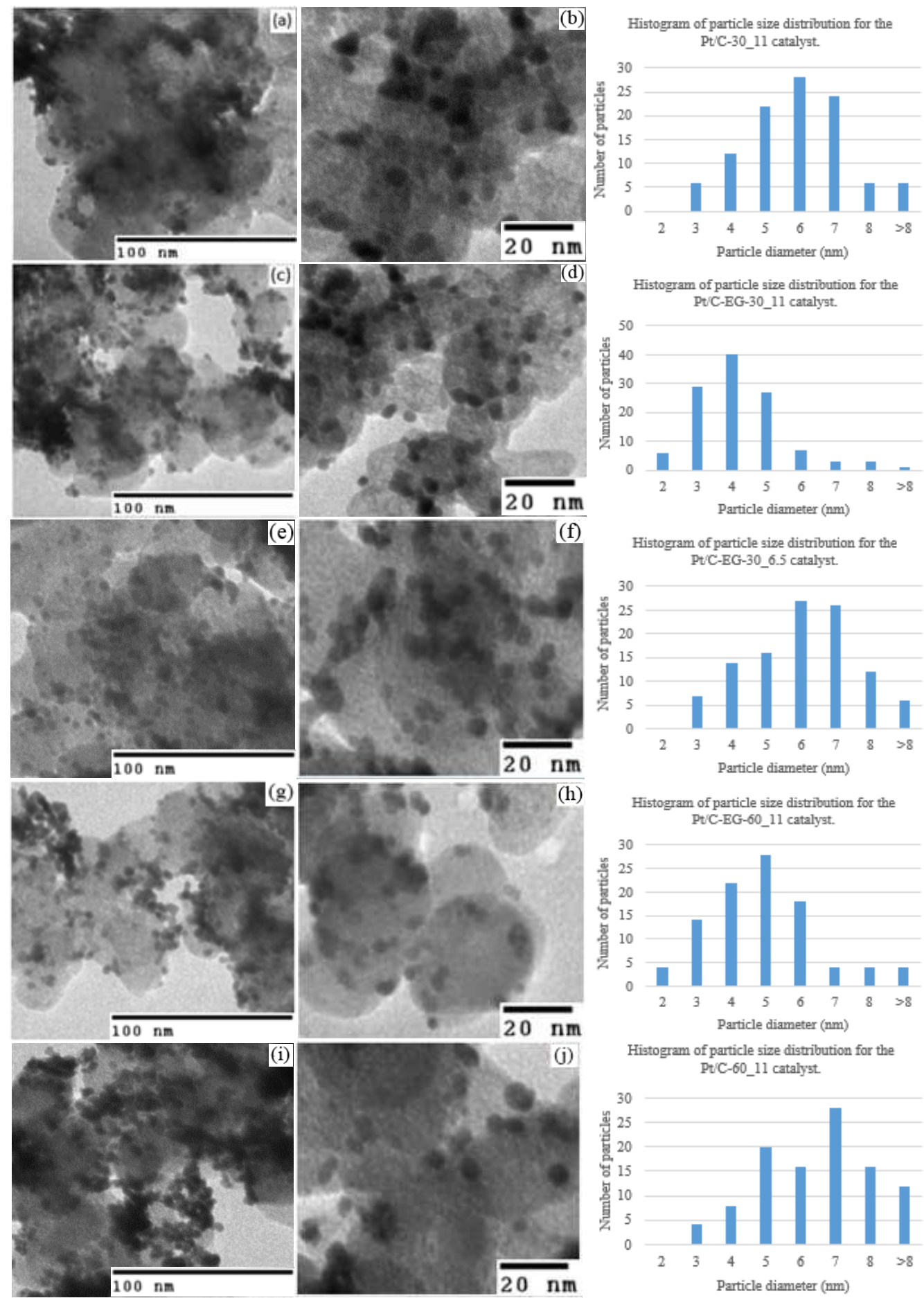

Histogram of particle size distribution for the Pt C-60_11 catalyst.

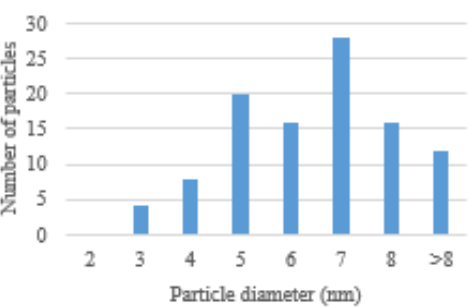

Figure 4. TEM pictures and histograms of particle size distribution for patterns of $40 \mathrm{wt} \% \mathrm{Pt} / \mathrm{C}$ catalysts. 
However, when the temperature increases from room temperature to $60{ }^{\circ} \mathrm{C}$, there is a significant difference in the crystallinity and the particles size of Pt on carbon. The Pt-EG-60_11 shows high crystallinity and large particle size compared to Pt-EG-30_11 (4.96 nm compare to $4.23 \mathrm{~nm})$ with the presence of EG or Pt-60_11 $(6.58 \mathrm{~nm})$ compare to Pt-30_11 (5.96 nm) without EG. This observation is then confirmed by calculating the average particle size from histogram of particle size distribution (Fig. 4), and the average size of Pt particles was shown in Table 3. The influence of temperature could be explained as follows: at a lower temperature, the formation of crystal nuclei proceeds more rapidly than the growth of it [16]. Therefore smaller Pt particles were obtained at $30^{\circ} \mathrm{C}$ compared to this obtained at $60{ }^{\circ} \mathrm{C}$.

Besides, the Pt/C-EG-30_6.5 catalyst has been synthesized in $\mathrm{pH}=6.5$ solution, compare to Pt/C-EG-30_11 catalyst (the same synthesis conditions, unlike $\mathrm{pH}$ ), the size of Pt particles in Pt/C-EG-30_6.5 catalyst is larger than the size of Pt particles in Pt/C-EG-30_11 catalyst. Bonnemann et al. reported that Pt nanoparticles are stabilized via electrosteric repulsion between the anionic surface of the Pt nanoparticle and the stabilizer [17]. In the acidic solution, a large number of $\mathrm{H}^{+}$ions interact with negatively charged $\mathrm{Pt}$ particles resulting in the destruction of electrosteric repulsion and leading to the growth of Pt nanoparticles. In the basic solution, almost no species would directly interact with negatively charged Pt nanoparticles, which implied that the electrosteric stabilization is unbroken $[17,18]$. A similar feature has also been observed in the synthesis of Pt-based metal nanoparticles using EG as a reducing agent $[19,20]$. In our case, the size of Pt nanoparticles of Pt/C-EG-30_6.5 sample is about $7.72 \mathrm{~nm}$ (Table 2) (estimated from the Scherrer formula at Pt (111) peak) or $6.08 \mathrm{~nm}$ (Table 3) (from histogram of particle size distribution (Fig. 4). The differences in Pt particles between Pt/C-EG-30_6.5 and Pt/C-EG30_11 can also be explained by the effect of electrosteric repulsion. Under high $\mathrm{pH}$ conditions, only minor interaction occurred between $\mathrm{H}^{+}$ions and stabilizer anions, yet the stabilizer strongly interacted with the reduced Pt nanoparticles. Therefore, the growth of Pt particles was significantly restrainted, leading to the formation of Pt nanoparticles with smaller size in the Pt/C-EG-30_11 than in the Pt/C-EG-30_6.5 catalyst.

Table 3. The average particle size and surface area were estimated from (***) and $(* *)$.

\begin{tabular}{lcc}
\hline Catalysts & $\mathbf{d}_{\text {TEM }}(\mathbf{n m})$ & $\mathbf{S}_{\mathbf{T E M}}\left(\mathbf{m}^{\mathbf{2}} / \mathbf{g}_{\mathbf{P t}}\right)$ \\
\hline Pt/C-30_11 & 5.96 & 47 \\
Pt/C-EG-30_11 & 4.23 & 66.3 \\
Pt/C-EG-30_6.5 & 6.08 & 46 \\
Pt/C-EG-60_11 & 4.96 & 56.5 \\
Pt/C-60_11 & 6.58 & 42.6 \\
\hline
\end{tabular}

From TEM pictures, estimating the average surface area of Pt nanoparticles on carbon support can also be carried out (Table 3), these result is corresponding to the XRD data that has been shown previously. The distribution and difference in the size of the catalyst particles strongly influenced the activity of the Pt/C catalysts. With the smallest size $(4.23 \mathrm{~nm})$, electrochemical active surface area of Pt in the Pt/C-EG-30_11 catalyst sample is largest (66.3 $\left.\mathrm{m}^{2} / \mathrm{g}_{\mathrm{Pt}}\right)$.

\subsection{Cyclic Voltammetry (CV) results}




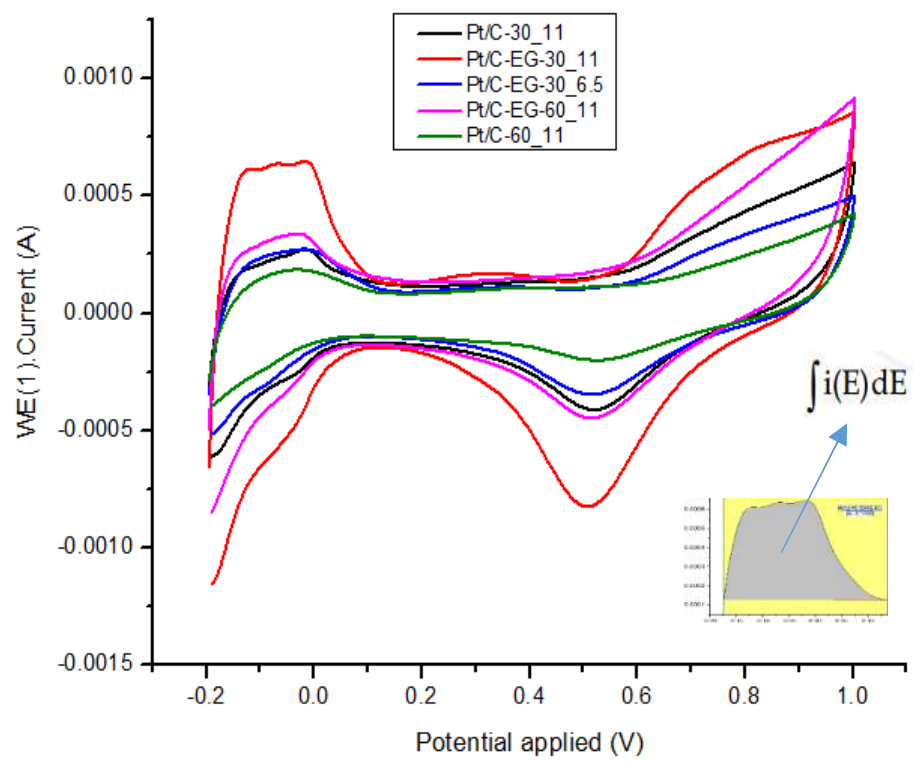

Figure 5. Cyclic voltammograms (CVs)for patterns of $40 \mathrm{wt} \% \mathrm{Pt} / \mathrm{C}$ catalysts were recorded in a $\mathrm{N}_{2}$-saturated $0.5 \mathrm{~mol} / \mathrm{L} \mathrm{H}_{2} \mathrm{SO}_{4}$ solution $\left(50 \mathrm{mV} / \mathrm{s}, 25^{\circ} \mathrm{C}\right)$.

The catalyst ink consist of $2.5 \mathrm{mg}$ of Pt/C $40 \mathrm{wt} \%, 1.0 \mathrm{ml}$ ethanol $\left(\mathrm{C}_{2} \mathrm{H}_{5} \mathrm{OH}\right)$ and $10 \mu \mathrm{l}$ nafion $5 \%$ solution were ultrasonicated in 30 minutes, a homogeneous solution ink was obtained. A small volume (15 $\mu \mathrm{l} / 3$ pipetting times) of this solution was pipetted onto a $6 \mathrm{~mm}$ diameter electrode containing a $3.2 \mathrm{~mm}$ diameter glassy carbon (GC) electrode and allowed to dry at room temperature for $30 \mathrm{~min}(10 \mathrm{~min} /$ pipetting once). The platinum loading on GC surface is $0.01 \mathrm{mg}$ (about $0.125 \mathrm{mg} . \mathrm{cm}^{-2}$ ). A three-electrodes cell was used in which the counter electrode was platinum, the reference electrode was $\mathrm{Ag} / \mathrm{AgCl}$ and working electrode was $\mathrm{GC}$. In the $\mathrm{CV}$ measurements, the potential values were converted automatically to normal hydrogen electrode (NHE) [21]. The CV curves were conducted in a $\mathrm{N}_{2}$-saturated $0.5 \mathrm{~mol} / \mathrm{L} \mathrm{H}_{2} \mathrm{SO}_{4}$ solution, the potential range from -0.2 to $1.0 \mathrm{~V}$ with scan rate $50 \mathrm{mV} / \mathrm{s}$ at room temperature and measured by the Autolab PGSTAT302N potentiostat/galvanostat, Metrohm Autolab brand.

Figure 5 is $\mathrm{CV}$ curves of $\mathrm{Pt} / \mathrm{C}$ catalysts in $\mathrm{H}_{2} \mathrm{SO}_{4} 0.5 \mathrm{M}$ solution. From the $\mathrm{CV}$ curves, it was easy to calculate the charge of the electrochemical processes which occur on the catalyst particles by integrating. As a result, the electrochemical surface area (ESA) showing the activity of the catalysts was estimated by the following formula [22,23]:

$$
S_{E S A-H}=\frac{Q_{H}}{[P t] \times Q_{\text {monolayer }}}=\frac{\frac{1}{\mathrm{v}} \times \int i(E) d E}{[P t] \times 2,1}
$$

where, $\mathrm{S}_{\mathrm{ESA}-\mathrm{H}}$ is electrochemically active surface area $\left(\mathrm{m}^{2} / \mathrm{g}_{\mathrm{Pt}}\right), \mathrm{Q}_{\mathrm{H}}$ is the charge for hydrogen desorption (C or A.s), $\int u(E) d E$ is integral of part hydrogen desorption (A.V), 2,1 is $\mathrm{Q}_{\text {monolayer }}$ $\left({\mathrm{C} . \mathrm{cm}^{-2}}^{-2}\right.$ (the charge related to the adsorption or desorption of a hydrogen monolayer on a polycrystalline $\mathrm{Pt}$ surface), $\mathrm{v}$ is scan rate $\left(\mathrm{mV} . \mathrm{s}^{-1}\right)$ and $[\mathrm{Pt}]$ represents the platinum loading in the electrode $(\mathrm{g})$. The resultant ESA values are listed in Table 4. 
Table 4. The average particle size and surface areas calculated from the $\mathrm{Pt}$ crystalline size $\left(\mathrm{S}_{\mathrm{XRD}}\right), \mathrm{Pt}$ particles size $\left(\mathrm{S}_{\mathrm{TEM}}\right)$ and electrochemically active surface area $\left(\mathrm{S}_{\mathrm{ESA}-\mathrm{H}}\right)$ :

\begin{tabular}{lc}
\hline Catalysts & $\mathbf{S}_{\text {ESA-H }}\left(\mathbf{m}^{2} / \mathbf{g}_{\mathbf{P t}}\right)$ \\
\hline Pt/C-30_11 & 21.9 \\
Pt/C-EG-30_11 & 95.2 \\
Pt/C-EG-30_6.5 & 31.3 \\
Pt/C-EG-60_11 & 31.4 \\
Pt/C-60_11 & 15.4 \\
\hline
\end{tabular}

On the CV curves (Fig. 5), there are the electrochemical peaks corresponding to the different electrochemical reactions on the samples' surface. In the potential range about- 0.15 $0.15 \mathrm{~V}$, the peaks express the adsorption/desorption processes of hydrogen on Pt crystal. The mechanism of these processes may take place by two stages. In the forward scan, the potential range from 0.15 to $0.58 \mathrm{~V}$ corresponds to the charge of the double layer by the oxygenated groups on the carbon support surface. At the potential $0.65 \mathrm{~V}$, the oxidation process of Pt metal happens to form Pt oxides. Corresponding with this process, there is a reduction peak at $0.51 \mathrm{~V}$ of reduction process of $\mathrm{Pt}-\mathrm{O}$ in the reverse scan [24, 25]. Among the peaks of the catalyst samples, those without $\mathrm{EG}$ or $\mathrm{pH}=6.5$ (acidic solution) are smaller than samples with EG and $\mathrm{pH}=11$ (basic solution). This means that the activity of these samples is relatively low. The activity of the catalyst synthesized with EG, $\mathrm{pH}=11$ at the room temperature (Pt/C-EG-30_11)is the highest. The calculated ESA values of the catalyst samples are shown in table 4. The difference in ESA value may be due to the difference in the size of Pt particles. With the biggest size of particles, the ESA value of thePt/C-60_11 sample is the smallest $\left(15.4 \mathrm{~m}^{2} / \mathrm{g}_{\mathrm{Pt}}\right)$ corresponding to desorption peak lowest. Possessing the smallest size, the ESA value of the $\mathrm{Pt} / \mathrm{C}-\mathrm{EG}-30 \_11$ sample is highest $\left(95.2 \mathrm{~m}^{2} / \mathrm{g}_{\mathrm{Pt}}\right)$. These results provide an extremely significant information about the relationship between the size and activity of the Pt nanoparticles catalyst on carbon support: The catalysts with smaller particle size will give a higher activity due to larger surface area. This trend also corresponds with the results of TEM and XRD analysis.

\section{CONCLUSIONS}

Through the influence of the synthesis conditions as temperature, $\mathrm{pH}$ and ethylene glycol on size and dispersion of platinum nanoparticles catalyst on carbon support were studied in this work, we found that the electrochemical surface area (ESA) was strongly influenced by the size and the size distribution of the Pt nanoparticles catalyst. As desired, the particle size and the distribution of $\mathrm{Pt}$ on carbon support can be controlled through adjusting synthesis conditions such as the temperature, EG enhancer and $\mathrm{pH}$ parameter. The results of this study showed the presence of EG with the function as a weak reducing agent and the stabilizer could enhance the distribution and make smaller Pt size compared to the sample without using EG. In addition, the effect of temperature on the $\mathrm{Pt} / \mathrm{C}$ preparation was studied at room temperature and $60{ }^{\circ} \mathrm{C}$, we also found that when the temperature increases from room temperature to $60{ }^{\circ} \mathrm{C}$, there is a significant difference about the crystallinity and the particles size of Pt on carbon. Finally, the effect of $\mathrm{pH}$ parameter on $\mathrm{Pt} / \mathrm{C}$ electrocatalyst indicated that the basic solution is better than acidic solution for synthesizing this catalyst. The results of this work showed the way to control 
size and distribution of Pt catalyst on carbon support that can be used to enhance the activity of $\mathrm{Pt} / \mathrm{C}$ catalyst with high loading for fuel cell applications.

Acknowledgment. This work was supported by Ho Chi Minh City University of Technology, University Of Science Ho Chi Minh City, Ho Chi Minh City University of Natural Resources and Environment.

\section{REFERENCES}

1. Hamnett A. - Mechanism and electrocatalysis in the directmethanol fuel cell, Catalysis Today 38 (1997) 445-457.

2. Markovic N. M., Ross Jr. P. N. - Surface science studies of model fuel cell electrocatalysts, Surface Science Reports 45 (2002) 117-229.

3. Armadi I. S., Wang Z. L., Green T. C., Henglein A., El-Sayed M. A. - Shape-Controlled Synthesis of Colloidal Platinum Nanoparticles, Science 272 (1996) 1924-1926.

4. Singh R. N., Awasthi R. and Sharma C. S. - Review: An Overview of Recent Development of Platinum Based Cathode Materials for Direct Methanol Fuel Cells, Int. J. Electrochem. Sci. 9 (2014) 5607-5639.

5. Liu Z. L., Lee J. Y., Han M., Chen W. X. and Gan L. M. - Synthesis and characterization of PtRu/C catalysts from microemulsions and emulsions, J. Mater. Chem. 12 (2002) 2453-2458.

6. Okitsu K., Yue A., Tanabe S., Matsumoto H. - Sonochemical preparation and catalytic behavior of highly dispersed palladium nanoparticles on alumina, Chem. Mater. 12 (2000) 3006-3011.

7. Tu W. and Liu H. - Rapid synthesis of nanoscale colloidal metal clusters by microwave irradiation, J. Mater. Chem. 10 (2000) 2207-2211.

8. Komarneni S., Li D., Newalkar B., Katsuki H., Bhalla A. S. - Microwave-polyol process for Pt and Ag nanoparticles, Langmuir 18 (2002) 5959-5962.

9. Coutanceau C., Baranton S. and Napporn T.W.. Platinum Fuel Cell Nanoparticle Syntheses: - Effect on Morphology, Structure and Electrocatalytic Behavior, The Delivery of Nanoparticles, Dr. Abbass A. Hashim (Ed.), InTech, Chapter 19 (2012) 403-426.

10. Senthil Kumar S. M., Hidyatai N., Herrero J. S., Irusta S., Scott K. - Efficient Tuning of the Pt Nano-Particle Mono Dispersion on Vulcan XC-72R by Selective Pre - Treatment and Electrochemical Evaluation of Hydrogen Oxidation and Oxygen Reduction Reactions, International journal of hydrogen energy 36 (2011) 5453-5465.

11. Lazaro M. J., Celorrio V., Calvillo L., Pastor E. and Moliner R. - Influence of the synthesis method on the properties of Pt catalysts supported on carbon nanocoils for ethanol oxidation, Journal of Power Sources 196 (2011) 4236-4241.

12. Shah M. A. - Growth of uniform nanoparticles of platinum by an economical approach at relatively low temperature, Scientia Iranica F 19 (2012) 964-966.

13. Zhou W. J., Li W. Z., Song S. Q., Zhou Z. H., Jiang L. H., Sun G. Q., Xin Q., Poulianitis K., Kontou S., Tsiakaras P. - Bi- and tri-metallic Pt-based anode catalysts for direct ethanol fuel cells, Journal of Power Sources 131 (2004) 217-223.

14. Joo J. B., Kim P., Kim W., Kim Y., Yi J. - Effect of the preparation conditions of carbonsupported Pt catalyst on PEMFC performance, J. Appl. Electrochem. 39 (2009) 135-140. 
15. Kim P., Joo J. B., Kim W., Kim J., Song I. K., Yi J. - $\mathrm{NaBH}_{4}$-assisted ethylene glycol reduction for preparation of carbon-supported Pt catalyst for methanol electrooxidation, Journal of Power Sources 160 (2006) 987-990.

16. Tian J. H., Wang F. B., Shan ZH. Q., Wang R. J. and Zhang J. Y. - Effect of preparation conditions of $\mathrm{Pt} / \mathrm{C}$ catalysts on oxygen electrode performance in proton exchange membrane fuel cells, Journal of Applied Electrochemistry 34 (2004) 461-467.

17. Bonnemann H., Braun G., Brijoux W., Brinkmann R., Schulze Tilling A., Seevogel K., Siepen K. - Nanoscale colloidal metals and alloys stabilized by solvents and surfactants Preparation and use as catalyst precursors, Journal of Organometallic Chemistry 520 (1996) 143-162.

18. Oh H. -S., Oh J. -G., Hong Y. -G., Kim H. - Investigation of carbon-supported Pt nanocatalyst preparation by the polyol process for fuel cell applications, Electrochimica Acta 52 (2007) 7278-7285.

19. Zhou Z., Zhou W., Wang S., Wang G., Jiang L., Li H., Sun G., Xin Q. - Preparation of highly active $40 \mathrm{wt} . \% \mathrm{Pt} / \mathrm{C}$ cathode electrocatalysts for DMFC via different routes, Catalysis Today 93-95 (2004) 523-528.

20. Bock C., Paquet C., Couillard M., Botton G. A., MacDougall B. R. - Size-Selected Synthesis of PtRu Nano-Catalysts: Reaction and Size Control Mechanism, Journal of the American Chemical Society 126 (2004) 8028-8037.

21. Khan A., Nath B. K., and Chutia J. - Nanopillar structured Platinum with enhanced catalytic utilization for electrochemical reactions in PEMFC, Electrochimica Acta 146 (2014) 171-177.

22. Pozio A., De Francesco M., Cemmi A., Cardellini F., Giorgi L. - Comparison of high surface Pt/C catalysts by cyclic voltammetry, Journal of Power Sources 105 (2002) 13-19.

23. Perez J., Gonzalez E. R., Ticianelli E.A. - Oxygen electrocatalysis on thin porous coating rotating platinum electrodes, ElectrochimicaActa 44 (1998) 1329-1339.

24. Takahashi I. and Kocha S. S. - Examination of the activity and durability of PEMFC catalysts in liquid electrolytes, Journal of Power Sources 195 (2010) 6312-6322.

25. Chaparro A. M., Martin A. J., Folgado M. A., Gallardo B. and Daza L. - Comparative analysis of the electroactive area of Pt/C PEMFC electrodes in liquid and solid polymer contact by underpotential hydrogen adsorption/desorption, International Journal of Hydrogen Energy 34 (2009) 4838-4846. 